\title{
Branding is the solution for product differentiation in Indian Dairy Industry
}

\author{
Dr.S.Franklin John* \& Ms.S.Senith** \& Ms.Reshma Ravindran*** \\ *Principal, Nehru college of Management, Coimbatore. \\ **Assistant Professor, Nehru college of Management, Coimbatore. \\ ***Student, Nehru College of Management, Coimbatore
}

\begin{abstract}
The study was designed to investigate the influence of Milk brand rating and different dimensions of milk brand. The study covers the population includes 325 consumers from Tamilnadu, who are all using branded milk. The questionnaires were given to 500 consumers who are all using branded milk. Out of 500 consumers contacted, 325 questionnaires were received with required coverage and details. The participants completed the two sets of self-reported questionnaires, including Background characteristics and variables chosen for this study in order to measure the influence of branded milk are the Salience, performance, Imagery, Judgment, Feelings and Resonance. The collected data were computed and analyzed via Descriptive statistics and one - way ANOVA.The findings of the study were generalized as follows: Statistically significant differences were found in the Milk brand rating and the different brand dimensions like Salience, Imagery ,Judgment, feelings and resonance and there is no statistically significant difference in dimension performance and Milk brand rating. In the end of the study implications and conclusion were provided.
\end{abstract}

\section{Introduction}

Dairy is a place where handling of Milk and Milk products is done and technology refers to the application of scientific knowledge for practical purposes .Dairy technology has been defined as that branch of dairy science which deals with the processing of Milk and the manufacture of Milk products on an industrial scale. In developed dairying countries such as the U.S.A, the year 1850 is seen as the dividing line between farm and factory scale production various factors contributed to this change in these countries Viz.Concentration of population in cities where jobs were plentiful rapid industrialization ,improvement of transportation facilities, development of machines etc., whereas the rural areas were identified for milk production, the urban centres were selected for the locations of Milk processing plants and product manufacturing factories. These plants and factories were rapidly expanded and modernized with improved machinery and equipment to secure the various advantages of large-scale production, nearly all the Milk in the U.S.A before 1900 was delivered as raw (natural) Milk. Once pasteurization was introduced, it developed rapidly, Mechanical refrigeration helped in the rapid development of the factory system of market milk distribution.

In India, dairying has been practiced as a rural cottage industry since the remote past some commercial dairying started with the establishment of military dairy farms and co-operative milk unions throughout the country towards the end of the nineteenth country. During the earlier years, each household in those countries maintained its family cow or secured milk from its neighbour who supplied those living close by. As the urban population increased fewer household could keep a cow for private use. The high cost of milk production, problems of sanitation etc., restricted the practice and gradually the family cow in the city was eliminated and city cattle were all sent back to the rural areas.

Gradually farmers within easy driving distance began delivering milk over regular routes in the cities. This was the beginning of the fluid milk sheds which surround the large cities of today prior to the 1850 s most milk was necessarily produced within a short distance of the place of consumption because of lack of suitable means of transportation and refrigeration. The Indian dairy industry has made rapid progress since independence. A large number of modern milk plants and product factories have since been established. These organized dairies have been successfully engaged in the routine commercial production of pasteurized bottled milk and various western and Indian dairy products with modern knowledge of the protection of milk during transportation, it became possible to locate dairies where land was less expensive and crops could be grown more economically.

In India, the market milk technology may be considered to have commenced in 1950, with the functioning of the central dairy of Aaray milk colony and milk product technology in 1956 with the establishment of the AMUL Dairy, Anand.The industry is still in its infancy and barely $10 \%$ of our total milk production under goes organized handling.In 1980s branded milk was a symbol of esteem .Now in 2007 majority of households in cities depends upon the Mother dairy or Amul for their daily milk supply. (Bhara, 
2008). India milk products for the global market using world class technology with the delicensing of the milk industry in the 90s, Global players like Nestle, Britannia,Smithkline ,Beecham and others pluged into the booming milk products market. Which was painstakingly established through the operation flood programme has become a household name with international standing, hundreds of small and medium players also have made a foray into this industry.(Vinod ,2004)

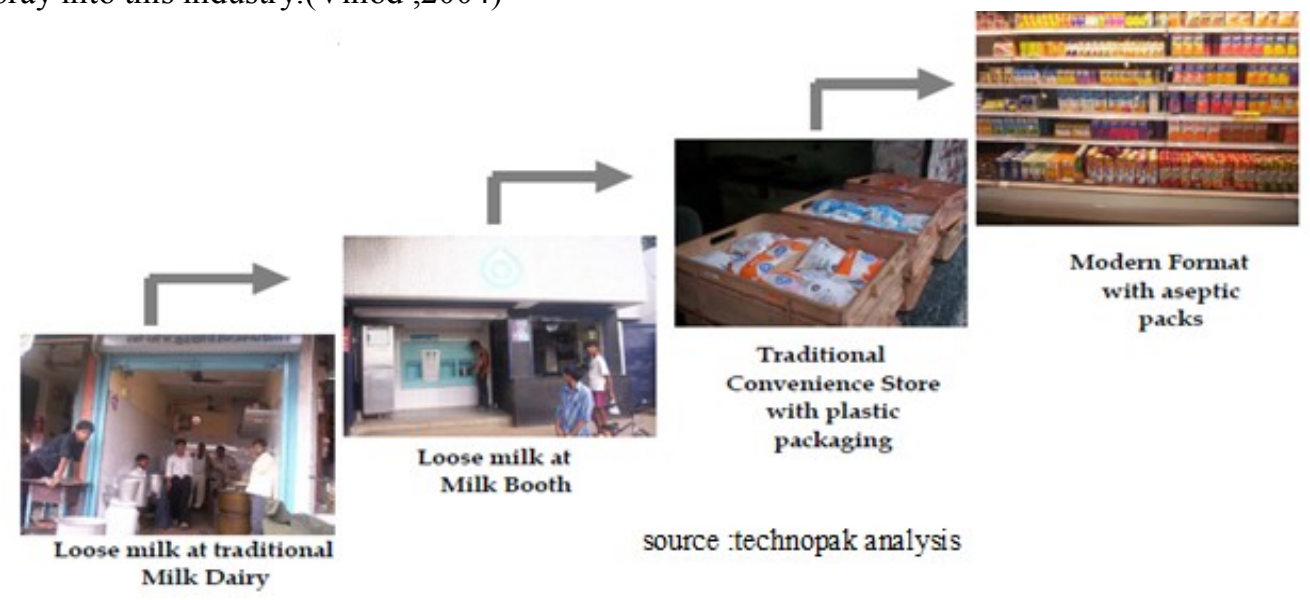

Milk was initially sold door to door by the local milk man. When the dairy cooperatives initially stated marketing branded milk. It was sold in glass bottles sealed with foil. Over the years several developments in packaging media have taken place .In the early 80 's plastic pouches replaced the bottles .Plastic pouches replaced the bottles .Plastic pouches made transportation and storage very convenient besides reducing costs. Milk packets in plastic pouches /bottles have shelf life of just 1-2 day that too only refrigerated .In 1996, Tetra packs were introduced in India Tetra packs aseptic lamination packs made of aluminium paper, board and plastic. Milk stored in tetra packs and treated under Ultra-high temperature (UHT) technique can be stored for four months without refrigerator Most of the dairy consumer -operatives in Andra Pradesh, Tamil Nadu, Punjab and Rajasthan sell milk in tetra packs.

\section{Review of Literature}

Integrated Brand Promotion (IBP) is the process of using a wide range of promotional tools working together to create wide spread brand exposure finally, the definition IBP specifies that all of the advertising and promotional effort undertaken by a firm is designed to create widespread exposure for a brand .Unless consumers are reached by these various forms of messages, they will have a difficult time understanding the brand and deciding whether to use it regularly. How does IBP fit in with advertisements and advertising campaigns? IBP is the use of many promotional tools including advertising in a coordinated manner to build and then maintain brand awareness, identity and preference. When Marketers combine contests, a website, and event sponsorship and point-of - purchase displays with advertisements and advertising campaigns they create an integrated brand promotion. (Thomas O'guinn et al, 2009) Advertising in Mass Media is defined as Non Personal Channels of broadcasting a message to the general public, principally the national newspaper, radio, television, magazines and Bill Boards (Business Dictionary .com).

(Kinnucan et al ,985) investigated that in the U.S dairy industry between ,1955 and 1980 the consumption of dairy on a milk -equivalent basis declined by $24 \%$ despite a $38 \%$ growth in population ,the total consumption of dairy products increased by less than $5 \%$ over the twenty-five-year period in order to face this problem dairy farmers have increased their investment in dairy promotion and advertising In the theoretical analysis Results suggest that appropriate timing of milk advertising expenditures can increase the effectiveness of the investment the ability of milk advertising to influence sales effect the profitability of the advertising investment . (Rebel Chad, 1996) Suggested that Milk sales had been in decline for nearly three decades. Vice chairman was in charge of the milk Must ache campaign. He chose to sink the entire dollar 36 million ad budgets in to Magazines Knowing TV would have used up the budget too quickly. By using magazines the agency was able to spread the campaign over 15 months. The campaign emphasized skim milk for its appeal to women who may not have drunk milk because of whole milk's high -fat content .The campaign was very successful. (Fond $\mathrm{Lu}, 1923$ ) Lac company one of the largest canned milk manufactures in the united states launch a program of National Publicity through pages in the Saturday evening post Bill Boards in one hundred cities and Newspaper Advertising the brand is Laurel the demand for which was to be increased by means of the national advertising, laurel milk was gaining its foothold of primary importance, more over was the fact that this decision of the company coordinated its entire brand policy with its national advertising plan. Mark Chou eke (2006) Nestle is launching Caribbean branded flavoured milk drink in UK market The thick creaming "on 
the go" milk drink is marketed as a nutritional supplement and is the leading brand with an $85 \%$ market share According to the supligen brand name is a well-known and will play well with the UK youth market. The key points that the Brand know the target audience is very influential on the wider youth culture is Radio Promotion ,street sampling ,music ,carnival and sport to spread the message. (Daniel Thomas, 2005) Milk Development council is to hit back at potentially dangerous dieting fads such as Atkins diet which restricts the intake of fullfat milk advertising campaign targeting teenage girls for the first time promoting the benefits of milk. The MDC survey shows that $74 \%$ of teenage girls avoid dairy products due to the lack of knowledge and a misconception that dairy products contains high levels of fat. DC marketing manager Vicky says that recent diet fads have had a huge impact on the body image of teenage girls $80 \%$ of those polled had concerns with body image $50 \%$ worries about being overweight The campaign which include cinema,Radio,Magazines and online advertising will teenagers about the beauty benefits of dairy products.

\section{Objectives of the study}

1. This study aimed to investigate the influence of Milk brand rating and different dimensions of milk brand

2. Does gender of the respondents influence dimensions of milk branding.

\section{Respondent sample}

In order to investigate the influence of milk brand in retail markets, a questionnaire was submitted to a random sample customers who are all using only branded milk interviewed by trained student Volunteers outside the Retail outlets and markets in Tamil Nadu. The data were collected in three month during the time in which people usually purchase brand milk (from $6 \mathrm{a}$ am. to $10 \mathrm{a}$.m. and from 3 to $6 \mathrm{p} . \mathrm{m}$.) 500 customers were contacted while leaving the Retail outlets and markets. 325 Questionnaires were received with required coverage details. due to the short time available for the interviews.

\section{Instrumentation}

The instruments of this study involved two parts: the first section of the instrument consisted of forcedchoice questions about demographic characteristics: gender, marital status, age, occupation, monthly income level. The second section variables chosen for this study in order to measure the influence of branded milk in Indian Retail Markets are taken from branding milk dimension contains of 60 items and characterized into six sub scales : (a) Salience (items 1 to 7), (b) Performance(items 8 to 13), (c) Imagery (items 14 to 18), (d) Judgment (items 19 to 36), (e) Feelings (items 37 to 42), (f) Resonance (items 43 to 60). The milk branding dimension 60 items are evaluated on a five-point Likert scale ranging from 1 to 5 , using the anchors " $5=$ stronglyagree, $4=$ agree, $3=$ Neutral, $2=$ Disagree, $1=$ Strongly disagree". Another scale of 1 to 10 was adopted to rank the overall Brand rating of Milk. A variety of scales are used to measure attitudes in behavioral science and marketing research studies. One often used scale is the ten-point, verbal-numerical scale as shown below. (William Reynolds, Nov 1996)

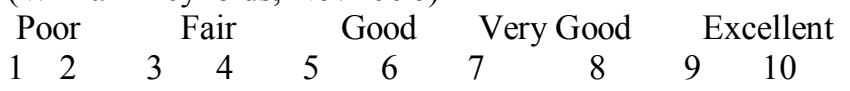

Cronbach,s alpha is a coefficient (a number between 0 and 1) that is used to rate the internal consistency (homogeneity) or the correlation of items in a test. If the test has a strong internal consistency most measurement experts agree that it should show only moderate correlation among items $(0.70$ to 0.90$)$. The reliability coefficients for the variables chosen for the study should have to be more than 0.70 , to consider it as an acceptable value (Nunally, 1978). In this study the Reliability analysis shows that all the factors have shown alpha value greater than 0.7 , indicating the evidence of reliability and the overall reliability of the instrument is 0.92 . So, the items constituting each variable under study have reasonable internal consistency and shows that all the dimensions of Branded Milk have a positive reliability. The factors and dimensions included for analysis carry a good degree of reliability to support the objectives formulated. All dimensions have got significant relationship to make the real representation of the study. Hence it is concluded that the data collected in this study is highly reliable.

\section{Data analysis}

The Statistical Package for the Social Science (SPSS) for Microsoft Windows 16.0 was used to complete the analysis of the collected data. Descriptive statistics, including means, standard deviations were implemented in order to investigate the demographic data, and the influence of branded milk,t-test, one-way analysis of variance (ANOVA) were used to determine whether any significant relationships exist among respondents. In addition, the .05 level of statistical significance was set at all statistical tests in the present study. 


\section{Results of Data Analysis}

\section{Analysis to find whether the selected dimensions influence brand rating}

The table -1 provides some very useful descriptive statistics including the mean, standard deviation for the dependent variables for all the groups (categories) and the F Value and significance value. Saliences of the product have statistically significance difference between brand ratings. Table-1 shows that consumers brand rating is high in excellent (mean =4.61) and consumer brand rating is low in poor (mean =2.29), Performance of the product have no statistically significance difference between brand rating Table-1 shows that consumers brand rating is high in excellent (mean=4.24) and consumer brand rating is low in poor (mean=3.08), Imagery of the product have statistically significance difference between brand rating Table-1 shows that consumers brand rating is high in excellent (mean=4.03) and consumers brand rating is low in poor (mean=2.40), Judgment of consumer towards their brand milk has statistically significance difference between brand ratings Table -1 shows that consumers brand rating is high in excellent (mean=4.55) and consumer brand rating is low in fair (mean=2.72), Feelings of consumer towards their brand milk have statistically significance difference between brand ratings Table -1 shows that consumers brand rating is high in excellent (mean=4.79) and consumer brand rating is low in fair (mean=2.46), Resonance has statistically significance difference between brand ratings. Table -1 shows that consumers brand rating is high in excellent (mean=4.74) and consumer brand rating is low in poor (mean=2.28), Homogeneity of variance assumption met for the entire dimension except performance .so for performance dimension instead of ANOVA table Robust Tests of Equality of Means referred.

Table - 1 Analysis of variance (ANOVA)

\begin{tabular}{|c|c|c|c|c|c|c|c|c|c|c|c|c|}
\hline \multirow{2}{*}{$\begin{array}{l}\text { Brand } \\
\text { rating }\end{array}$} & & \multicolumn{10}{|c|}{ Mean ( Standard Deviation)Scores } & \multirow[b]{2}{*}{ Sig } \\
\hline & G1 & G2 & G3 & G4 & G5 & G6 & G7 & G8 & G9 & G10 & $\mathrm{F}$ & \\
\hline $\begin{array}{c}\text { Salienc } \\
\mathrm{e}\end{array}$ & - & $\begin{array}{c}2.29 \\
(.606)\end{array}$ & $\begin{array}{c}3.39 \\
(.376)\end{array}$ & $\begin{array}{c}3.69 \\
(.445) \\
\end{array}$ & $\begin{array}{c}3.70 \\
(.635)\end{array}$ & $\begin{array}{c}3.90 \\
(.549)\end{array}$ & $\begin{array}{r}3.99 \\
(.572) \\
\end{array}$ & $\begin{array}{c}3.85 \\
(.535)\end{array}$ & $\begin{array}{c}3.95 \\
(.391) \\
\end{array}$ & $\begin{array}{c}4.61 \\
(.500) \\
\end{array}$ & 4.93 & .000 \\
\hline $\begin{array}{l}\text { Perfor } \\
\text { mance }\end{array}$ & - & $\begin{array}{c}3.08 \\
(1.06)\end{array}$ & $\begin{array}{c}3.13 \\
(.370)\end{array}$ & $\begin{array}{c}3.63 \\
(.321)\end{array}$ & $\begin{array}{c}3.36 \\
(.588)\end{array}$ & $\begin{array}{c}3.58 \\
(.528)\end{array}$ & $\begin{array}{c}3.65 \\
(.594)\end{array}$ & $\begin{array}{c}3.60 \\
(.512)\end{array}$ & $\begin{array}{c}3.52 \\
(.392)\end{array}$ & $\begin{array}{c}4.24 \\
(.816)\end{array}$ & 1.44 & .259 \\
\hline $\begin{array}{c}\text { Imager } \\
\mathrm{y}\end{array}$ & - & $\begin{array}{c}2.40 \\
(.283)\end{array}$ & $\begin{array}{c}2.60 \\
(.365)\end{array}$ & $\begin{array}{c}2.92 \\
(.729)\end{array}$ & $\begin{array}{c}2.93 \\
(.798)\end{array}$ & $\begin{array}{c}3.18 \\
(.656)\end{array}$ & $\begin{array}{c}3.21 \\
(.646)\end{array}$ & $\begin{array}{c}3.37 \\
(.655)\end{array}$ & $\begin{array}{c}3.40 \\
(.668)\end{array}$ & $\begin{array}{c}4.03 \\
(.948)\end{array}$ & 3.30 & .001 \\
\hline $\begin{array}{c}\text { Judgm } \\
\text { ent }\end{array}$ & - & $\begin{array}{c}2.85 \\
(.118)\end{array}$ & $\begin{array}{c}2.72 \\
(.299)\end{array}$ & $\begin{array}{c}3.72 \\
(.276)\end{array}$ & $\begin{array}{c}3.63 \\
(.470)\end{array}$ & $\begin{array}{c}3.51 \\
(.418)\end{array}$ & $\begin{array}{c}3.67 \\
(.535) \\
\end{array}$ & $\begin{array}{c}3.75 \\
(.474)\end{array}$ & $\begin{array}{c}3.79 \\
(.359)\end{array}$ & $\begin{array}{c}4.55 \\
(.546) \\
\end{array}$ & 7.51 & .000 \\
\hline $\begin{array}{c}\text { Feeling } \\
\mathrm{s}\end{array}$ & - & $\begin{array}{c}3.17 \\
(.471)\end{array}$ & $\begin{array}{c}2.46 \\
(.250) \\
\end{array}$ & $\begin{array}{c}3.47 \\
(.431) \\
\end{array}$ & $\begin{array}{c}3.43 \\
(.587) \\
\end{array}$ & $\begin{array}{c}3.43 \\
(.531) \\
\end{array}$ & $\begin{array}{c}3.59 \\
(.590) \\
\end{array}$ & $\begin{array}{c}3.66 \\
(.500) \\
\end{array}$ & $\begin{array}{c}3.79 \\
(.611) \\
\end{array}$ & $\begin{array}{c}4.79 \\
(.393) \\
\end{array}$ & 8.07 & .000 \\
\hline $\begin{array}{c}\text { Resona } \\
\text { nce }\end{array}$ & - & $\begin{array}{c}2.28 \\
(.009)\end{array}$ & $\begin{array}{c}2.37 \\
(.329)\end{array}$ & $\begin{array}{c}2.94 \\
(.220)\end{array}$ & $\begin{array}{c}3.14 \\
(.388) \\
\end{array}$ & $\begin{array}{c}3.35 \\
(.352)\end{array}$ & $\begin{array}{c}3.41 \\
(.399) \\
\end{array}$ & $\begin{array}{c}3.68 \\
(.344)\end{array}$ & $\begin{array}{c}3.73 \\
(.339) \\
\end{array}$ & $\begin{array}{c}4.74 \\
(.443) \\
\end{array}$ & 26.5 & .000 \\
\hline
\end{tabular}

Note: G1-poor, G2-poor, G3-Fair, G4-Fair, G5-Good, G6-Good, G7-Very Good, G8-Very Good, G9Excellent, G10-Excellent.

From the above table we can see that in this the significance level of Salience is $0.000(P=.000)$, which is below 0.05 and, therefore, there is statistically significant difference between salience of branding by brand rating, significance level of Performance is $0.259(\mathrm{P}=.259)$ which is above 0.05 and therefore there is no statistically significant difference between performance of branding by brand rating, significance level of Imagery is $0.001(\mathrm{P}=.001)$ which is below 0.05 and, therefore, there is statistically significant difference between Imagery of branding by brand rating, Significance level of Judgment is $0.000(\mathrm{P}=.000)$ which is below 0.05 and, therefore, there is statistically significant difference between Judgment of branding by brand rating, significance level of Feelings is $0.000(\mathrm{P}=0.000)$ which is below 0.05 and, therefore, there is statistically significant difference between Feelings of branding by brand rating. Significance level of Resonance is 0.000 $(\mathrm{P}=.000)$ which is below 0.05 and, therefore, there is statistically significant difference between Resonance of branding by brand rating.

\section{Homogeneity of Variances Table}

The table Test of Homogeneity of Variances (see below) shows the result of Levene's Test of Homogeneity of Variance, which tests for similar variances. If the significance value is greater than 0.05 (found in the Sig. column) then we have homogeneity of variances. We can see from this that Levene's $F$ Statistic has a significance value of Salience is 0.616 , Performance is 0.816 , Imagery is 0.188 , Judgment is 0.063 , Feelings is 0.271 , Resonance is 0.374 and, therefore, the assumption of homogeneity of variance is met.

Table -1.1 Test of Homogeneity of Variances

\begin{tabular}{|c|c|c|c|c|}
\hline Brand rating & Levene statistic & Df1 & Df2 & Sig \\
\hline Salience & 0.785 & 8 & 316 & 0.616 \\
\hline Performance & 2.210 & 8 & 316 & 0.027 \\
\hline Imagery & 1.418 & 8 & 316 & 0.188 \\
\hline Judgment & 1.878 & 8 & 316 & 0.063 \\
\hline Feelings & 1.247 & 8 & 316 & 0.271 \\
\hline Resonance & 1.085 & 8 & 316 & 0.374 \\
\hline
\end{tabular}




\section{Analysis to find the significant difference in various dimensions of Branding by the Gender of respondents.}

The Group statistics table -2 provides some very useful statistics including the mean, standard deviation and standard error for the dependent variables when two groups (male, female) and the combined (Total). Salience of the product does not reveal statistically significant difference by gender of respondents.Table-2 shows that female respondents are more aware of branded milk (mean=3.95) than male respondents the mean score is less (mean=3.90), Performance of the product have no statistically significant difference by gender of the respondents. Table- 2 shows that female respondents have more satisfaction towards performance of branded milk (mean=3.63) than male respondents the mean score is less (mean=3.56), Imagery of the product have statistically significant difference by gender of the respondents. Table- 2 shows that female respondents are more attached with branded milk (mean=3.32) than male respondents the mean score is less (mean=3.12), Judgment of the product have statistically significant difference by gender of the respondents. Table-2 shows that female respondents are more satisfied with the quality of the product and creditability is high towards the producers, and their opinion about brand of milk is superior than other brand of milk (mean=3.70) than male respondents the mean score is less $(\operatorname{mean}=3.58)$, Feelings of consumer about their brand of milk have statistically significant difference by gender of the respondents. Table- 2 shows that female respondents have high positive feelings towards brand of milk (mean=3.63) than male respondents the mean score is less (mean $=3.50$ ), Resonance of product have statistically significant difference by gender of the respondents. Table2 shows that female respondents are more loyal and commitment towards brand of milk (mean=3.51) than male respondents the mean score is less $($ mean $=3.40)$

\section{Table-2 Group Statistics}

\begin{tabular}{|c|c|c|c|c|c|c|c|}
\hline \multirow{2}{*}{ Gender } & \multicolumn{3}{|c|}{ Mean } & \multicolumn{3}{c|}{ Standard Deviation } \\
\cline { 2 - 7 } & $\mathbf{N}$ & Male & Female & Total & Male & Female & Total \\
\hline Salience & 325 & 3.90 & 3.92 & 7.82 & 0.582 & 0.563 & 0.115 \\
\hline Performance & 325 & 3.56 & 3.63 & 7.19 & 0.514 & 0.583 & 0.101 \\
\hline Imagery & 325 & 3.12 & 3.32 & 6.44 & 0.673 & 0.681 & 0.135 \\
\hline Judgment & 325 & 3.58 & 3.70 & 7.28 & 0.519 & 0.495 & 0.101 \\
\hline Feelings & 325 & 3.50 & 3.63 & 7.13 & 0.598 & 0.587 & 0.117 \\
\hline Resonance & 325 & 3.40 & 3.51 & 6.91 & 0.469 & 0.465 & 0.936 \\
\hline
\end{tabular}

\section{Homogeneity of Variances Table \& T-test for Equality of mean}

The table Test of Homogeneity of Variances (see below) shows the result of Levene's Test of Homogeneity of Variance, which tests for similar variances. If the significance value is greater than 0.05 (found in the Sig. column) then we have homogeneity of variances. We can see from this that Levene's $F$ Statistic has a significance value of Salience is 0.867 , Performance is 0.145 , Imagery is 0.846 , Judgment is 0.622 , Feelings is 0.857 , Resonance is 0.889 and, therefore, the assumption of homogeneity of variance is met.

Table - 2.1 Test of Homogeneity of Variances for T-test

\begin{tabular}{|c|c|c|c|c|c|}
\hline \multirow{2}{*}{ Gender } & \multicolumn{2}{|c|}{ Levene's test for equality of variance } & \multicolumn{2}{c|}{ t-test for equality of } \\
\cline { 2 - 6 } & Levene statistic & Sig & t-test & df & Sig(2-tailed) \\
\hline Salience & 0.028 & 0.867 & -.380 & 323 & 0.704 \\
\hline Performance & 2.135 & 0.145 & -1.079 & 323 & 0.281 \\
\hline Imagery & 0.038 & 0.846 & -2.513 & 323 & 0.012 \\
\hline Judgment & 0.224 & 0.622 & -2.122 & 323 & 0.035 \\
\hline Feelings & 0.033 & 0.857 & -2.022 & 323 & 0.044 \\
\hline Resonance & 0.019 & 0.889 & -1.982 & 323 & 0.048 \\
\hline
\end{tabular}

Hence homogeneity of variance is met from the T-test for Equality of mean table see Equal variance assumed for $\operatorname{sig}$ (2-tailed). As in all statistical tests, the basic criterion for statistical significance is a "2-tailed significance" less than 0.05. significance level of Salience is $0.704(P=.704)$, which is above 0.05 and, therefore, there is no statistically significant difference between salience of branding by Gender of respondents, significance level of performance is $0.281(\mathrm{P}=.281)$ which is above 0.05 and, therefore, there is no statistically significant difference between Performance of branding by Gender of respondents, significance level of Imagery is $0.012(\mathrm{P}=.012)$ which is below 0.05 and, therefore, there is statistically significant difference between Imagery of branding by Gender of respondents, significance level of Judgment is $0.035(\mathrm{P}=.035)$ which is below 0.05 and, therefore, there is statistically significant difference between Judgment of branding by Gender of respondents, significance level of Feelings is $0.044(\mathrm{P}=.044)$ which is above 0.05 and, therefore, there is statistically significant difference between Feelings of branding by Gender of respondents, Significance level of Resonance is $0.048(\mathrm{P}=.048)$ which is below 0.05 and, therefore, there is statistically significant difference between Resonance of branding by Gender of respondents. 


\section{Findings and Discussions}

Salience of branding is statistically significant by brand rating. From that we can found that consumers have more awareness about brand milk they can easily recognize the name of the brand, easily identify the logo of the brand milk they usually prefer branded milk. Salience of the product does not reveal statistically significant difference by gender of respondents. Table -2.1 shows the $t$ - test for equality of mean in that salience has no statistically significant difference by Gender of the respondents.

Performance is statistically insignificance difference between brand ratings. From that we can found that even though the brand milk is not so tasty, prices are not reasonable, consumers have few complaints about their brand milk they prefer to buy brand milk. Performance of the product has no statistically significant difference by gender of the respondents. Table-2.1 shows the t-test for equality of mean in that performance has no statistically significant difference by Gender of the respondents

Imagery has statistically significant difference by brand rating. From that we can found that ease of purchase is more. Consumers are satisfied to be attached with brand of milk Imagery of the product have statistically significant difference by gender of the respondents.

Judgment has statistically significant difference by brand rating. Consumers have satisfaction towards the quality of the product and good opinion about the producers they have superiority over their brand of milk. Table -2.1 shows the t-test of equality of mean in that Imagery has statistically significant difference by Gender of the respondents.

Feelings have statistically significant difference by brand rating. Therefore consumers have positive feeling towards their brand of milk. Imagery of the product has statistically significant difference by gender of the respondents. Table- 2.1 shows the t-test of equality of mean in that Imagery has statistically significant difference by Gender of the respondents

Resonance has statistically significant difference by brand rating. Therefore we can find that consumers are loyal their brand of milk and they are highly attached with branded milk. Resonance of product have statistically significant difference by gender of the respondents, Table -2.1 shows the t-test of equality of mean in that resonance has statistically significant difference by Gender of the respondents.

\section{Conclusion}

From the literature we come to understand that day by day competition in the retail market is increasing .Every week new product or extended product is getting introduced for consumers in the retail sector. As we know in dairy industry which is attached to the consumer emotionally and it was largely dominated by private vendors and unorganized retail sector. Due to the globalization and liberalization lot of foreign players have entered into the dairy sector. From the study we come to know that customers purchase or select their product by the brand .It implies that the product should have a good quality of a known brand which is price effective and satisfies the needs and wants of the customer. It implies that the customers can identify the product by their brand .So the manufacturers of dairy products have to be very cautious in managing their brand otherwise another strong brand will take over the existing customers

\section{References}

[1]. Armitt, claire (2004) case study, new media age.p28-28,1/2p,1 color photograph

[2]. Beck, robert 1(1974) consumer gain from private labeling of milk,journal of consumer affairs, vol.8,issue 2,p194,4p.

[3]. Benton etal (2007) impact of consuming a milk drink containing a probiotic on mood and cognition,european journal of clinical nutrition,vol .61,issue3,p355-361,7p,1 chart,3 graphs.

[4]. Bianco, david,ed(1993)pr news case book:1000 public relations case studies gale research.

[5]. Bittar, christine (2003)milk, hold the cholestral, brand week, vol44, issue 21,p10,1/3p.

[6]. Blattberg,robert c,scott a.neslin (1990)sales promotion:concepts,methodsand strategies,prentice hall.

[7]. Bokale, jemima (2007) waitrose invests in eco-friendly milk packaging, marketing (00253650),p4-4,1/5 p,1 color photograph.

[8]. Brian beattie (2002)arla lifts lid on database drive for milk brand,precision marketing, vol.14,issue 44,p6,1/6p,1 color photograph.

[9]. Bruce harte (2001) milk packaging its more than a container,dairy foods,vol 102,issue 6,5p,3 color photo graphs.

[10]. Cal crandall (1986)marketing briefs, marketing new, vol.20,issue 22,p15-15,1/7 p.

[11]. Carol wham (2000) changing new zealanders attitudes to milk.thesis submitted in fulfillment of the requirements for phd.

[12]. Carolyn dimitri and kathryn m.venezia (2007) retail and consumer aspects of the organic milk market/ldp-m-155-01 ,economic research service /usda.

[13]. Cartons are cat's whiskers,packaging magazine;9/9/2004,vol.7,issue 16,p14-14,1/4p.

[14]. Central statistical organization (cso)2006,growth rates:goldman sach's bric report.

[15]. Chaitanya prasad giri (2009) branding strategies for the future,a lesson from past experience,advertising express ,p40-40.

[16]. Cherish mathew (2009)organized retail business opportunity or threat? marketing mastermind ,the icfai university press, reference\#10m-2009-06-06-01.

[17]. Chiara taglioni (2010)influence of brand equity on milk's choice:a survey through choice.Cchurning up awards.dairy industries international ,feb2006, vol 71, issue 2,p6-6,1/9p.

[18]. Daniel thomas (2005) milk development council ads to target teenage girls,marketing week(01419285) vol 28,issue 2,p6-6,1/3p.

[19]. David diggens(2005) superheros to front milk drink brand,marketing week(01419285), vol.28,issue 32,p6-6,1/5 p,1 color photograph.

[20]. Denford chimboza and edward mutandwa(2007)measuring the brand preference in a dairy product market,issn 1993-8233@2007 academic journals. 
[21]. Dominkowski,john (2001) wmmb gives away bug to promote milk,dairy foods,vol.102,issue 10,p16,1/2p,1 color photograph.

[22]. Dr.s.l.gupta (2005) brand management (an indian perceptive )himalaya publishing house.

[23]. Dudlicek,james (2009) pushing the line, dairy foods,voll 10,issue4,p70-71,2p,1 color photograph.

[24]. Dudlicek,james(2009) cash and caring, dairy foods,vol.110,issue 3,p108-110,2p,2 color photograph.

[25]. Duncan,jenna (2008)more grocery stores branding rbst-free milk, drug store news,vol.30,issue5,p65-72,2p

[26]. Eduardo tricio and rick beaman(2009)grupo lala buys ndh from dfa ,dairy foods,vol 110,issue 6,p12-12,1p.

[27]. Edward nash (2000) direct marketing strategy planning ,copy right 2000,1995,1986,1982 by the mcgraw-hill companies,inc.all rights reserved.

[28]. Ernst\& young(2006) the great indian retail story.

[29]. Feller, michael (2008)campina turns to branded milk,dairy industries international,vol 73,issue 7,p8-8,1/9p.

[30]. Ficci-icici property services study

[31]. Fitzgerald (2005)adding value to milk through innovation,dairy foods ,vol 106,issue 12,4p,1 color photograph,1 diagram.

[32]. Fond lu lac co(jul23)the utilization of an acquired competitive brand,harvard business review,vol.1,issue 4,p499-502,4p.

[33]. Frances b.smith (2004) proposed milk price cartel would hurt consumers, consumer comments, vol.28,issue 2,p1-1,1/6p.

[34]. Frank fuller,john beghin,scott rozelle(2007)consumption of dairy products in urban china results from beijing,shangaiand guangzhou,australian journal of agricultural resource economics, vol51,issue 4,p459-470,16p,8 charts.

[35]. Gay,verne(2000)milk,the magazine,american demographics,vol 22,issue2,p32,3p,1 color photograph

[36]. Harsh v verma(2008)brand management.

[37]. Houston(2004) got milk campaign teams with nfl players to get fit,club industry (07478283),vol.20,issue2,p12-12,2/3p

[38]. hui's geertje,arjan(2004) high speed milk, dairy industries international ,vol69, issue11,p3 0-32,3p.

[39]. jane lu hsu,gary shang-min liu (2000) consumer perceptions of fluid milk advertising in taiwan,international journal of advertising vol 19,issue 4,p471-486,16p,10 charts,1 graphs.

[40]. kaitibie s,omore a,rich k,salasya b,hooton n,mwero d and kristjanson $p(2009)$ influence pathways and economic impacts of policy change in the kenyan dairy sector,research report 15 ,ilri nairobi,kenya.58pp.

[41]. kevin lane keller(2008)strategic brand management building,measuring and managing brand equity prentice -hall of india .privated limited.

[42]. kinnucan ,henry,forker and olan,d.(1985) seasonality in the consumer response to milk advertising with implication for milk promotion policy,american journal of agricultural economics;aug ,vol.68, issue 3,p 562,10p.

[43]. ko floor(2006)branding a store,bis publishers , amsterdam.let gradualism guide fdi in retail economist,2006.

[44]. liu,donald $\mathrm{j}$,forker,olan d (1990) optimal control of generic fluid milk advertising expenditures,american journal of agricultural economics,vol.72,issue4,p1047,9p,1 chart,2graphs.

[45]. manafy,michelle (2009) free milk and the price of beef,econtent,apr,vol.32,issue 3,p4-4,1p

[46]. mark choueke(2006) nestle to target uk youth market with caribbean nutritional drink, marketing week(01419285)vol 29,issue $14, \mathrm{p} 9-9,1 / 3 \mathrm{p}$.

[47]. marketing mastermind,dec 2009,icfai university press.

[48]. mecracken brooks.(1999) new promotion, dairy foods, sep,vol.100,issue 9,p32,1/2p,1 color photograph.

[49]. neil kennedy(2009) branded products help boost friesland campina results, dairy industries international,vol.74,issue 10,p8-8,1/7p.

[50]. nigel motts (2006) uganda dairy processors assistance project final technical report award\#gdg-g-00-02-00010-00.

[51]. paul fraser (2008) dairy crest set to rebrand milk lines as country life,marketing week(01419285), vol.31, issue 40,p5 $-5,1 / 5 \mathrm{p}$.

[52]. pelletier,david 1,kendal and anne (1999)nutrition and dairy industry benefits associated with promoting lowfat milk,family economics \& nutrition review, vol 12 ,issue 1,p3,11p,4charts, 1graph.

[53]. penny baker (2006) wake up to weight loss,frozen food age,vol.54,issue 11,p27-29,2p

[54]. philips, david (2005)wrap it up,dairy foods, vol .106,issue 6,p24-30,5p.

[55]. pradip kumar deb (2010)managing brands in a changing world,the journal of aima (all india management association)vol;49, issue 7.

[56]. quackenbush,gerald g.(1966)the ada/usda milk promotion study, journal of farm economics;aug (part1) vol.48, issue 3,p756,3p.

[57]. ramanathan(2009)the new face of unorganized retailers in india,marketing mastermind,reference\#10m-2009-05-08-01.

[58]. rentas-giusti,laura(2003) local milk producers launch first branded advertising efforts,caribbean business ,vol.31,issue 18,p38,2p,6 color photograph. 